\title{
Aktivitas Antibakteri Ekstrak Etanol Daun Sembung Rambat \\ (Mikania micrantha Kunth)
}

\author{
Santi Perawati *, Lili Andriani, Putri Pratiwi \\ Stikes Harapan Ibu Jambi, Jl. Tarmizi Kadir No.71 Pakuan Baru, Jambi \\ Program Studi Farmasi, Stikes Harapan Ibu Jambi \\ e-mail: *santiperawati@gmail.com
}

Diterima: 13 September 2018 / Disetujui: 6 Desember 2018 / Dipublikasi online: 15 Desember 2018 DOI: $10.22437 /$ chp.v3i2.5554

\begin{abstract}
Mikania micrantha leaves are traditionally used as drugs wound. It is therefore suspected that the plant is potentially as antibacterial. The purpose of this research is to know the potential leaves of Mikania micrantha as antibacterial Staphylococcus aureus. Powder leaves of Mikania micrantha in maceration with ethanol 70\%, followed by a test of phytochemicals. Then do antibacterial activity with disc method against the bacteria Staphylococcus aureus with concentration variations of 5\%,15\% and 25\%. From maceration, it got rendemen of $9.37 \%$ yield. Test positive phytochemicals contain alkaloids, flavonoids, saponins, polyphenols, and steroids. Testing of antibacterial activity of Staphylococcus aureus have strong inhibitory power category at all concentrations. Mikania micrantha leaves extract has higher antibacterial activity against Staphylococcus aureus bacteria.
\end{abstract}

Keywords: Mikania micrantha Kunth; phytochemicals; antibacterial; Staphylococcus aureus

\section{ABSTRAK}

Daun sembung rambat secara tradisional digunakan sebagai obat luka. Oleh karena itu diduga tumbuhan tersebut berpotensi sebagai antibakteri. Tujuan penelitian ini adalah untuk mengetahui potensi daun sembung rambat sebagai antibakteri Staphylococcus aureus. Serbuk daun sembung rambat dimaserasi dengan etanol 70\%, dilanjutkan dengan uji fitokimia. Kemudian dilakukan uji aktivitas antibakteri menggunakan metode cakram terhadap bakteri Staphylococcus aureus variasi konsentrasi 5\%, 15\%, dan 25\%. Dari hasil maserasi didapatkan rendemen sebesar 9,37\%. Uji fitokimia positif mengandung alkaloid, flavonoid, polifenol, saponin, dan steroid. Uji aktivitas antibakteri Staphylococcus aureus memiliki kategori daya hambat kuat pada semua konsentrasi. Ekstrak daun Sembung Rambat memiliki aktivitas antibakteri yang kuat terhadap bakteri Staphylococcus aureus

Kata Kunci: Mikania micrantha Kunth; uji fitokimia; antibakteri; Staphylococcus aureus

\section{PENDAHULUAN}

Mikania micrantha Kunth atau dikenal dengan nama Sembung Rambat, merupakan salah satu spesies dari famili Asteraceae, dimana tumbuhan ini telah digunakan sebagai obat tradisional, seperti mengobati gigitan serangga atau sengatan kalajengking, untuk mengobati penyait kulit seperti ruam dan gatal-gatal kulit (Li et al, 2013), juga dapat mengobati diabetes, stroke, hiperkolesterolemia, dan hipertensi dengan mengkonsumsinya dalam bentuk jus (dibuat dengan metode rebusan). Selain itu, daunnya dapat digunakan untuk mengobati sakit perut, sakit kuning, ditempatkan di bak air hangat untuk wanita setelah persalinan, demam, rematik, dan penyakit pernafasan (Chetia, Upadhyaya, \& Bora, 2014). Tumbuhan ini juga memiliki khasiat diantaranya sebagai antitumor, sitotoksik, analgesik, antiinflamasi, antiproliferatif, dan phytotoxic (Lallianchhunga et al, 2016). 
Daun sembung rambat juga mengandung zat aktif dalam bentuk metabolit sekunder diantaranya yaitu saponin, flavonoid, steroid, tannin, dan terpenoid. Senyawa metabolit sekunder yang berperan sebagai antibakteri yaitu flavonoid dan tannin (Polakitan et al., 2017; Haisya et al., 2013). Selain itu, daun sembung rambat memiliki kandungan volatil antara lain a-pinene, camphene, $\beta$-pinene, a-felandrene, $\beta$-ocimene, linalool, geranyl acetate, terpenol, geraniol, dan thymol (Perez-amador et al, 2010).

Penelitian terkait bioaktivitas daun Sembung Rambat sebagai antibakteri masih jarang dilaporkan (Matawali et al, 2016). Penelitian ini bertujuan untuk mengetahui potensi daun Sembung Rambat sebagai antibakteri. Selain itu juga untuk menginvestigasi metabolit sekunder yang ada pada sampel melalui uji skrining fitokimia. Data ini diharapkan nantinya akan bermanfaat untuk penelitian lanjutan terkait identifikasi, dan karakterisasi terhadap metabolit sekunder yang diduga berperan dalam aktivitas antibakteri.

\section{METODOLOGI PENELITIAN}

Bahan

Bahan yang digunakan yaitu simplisia daun sembung rambat yang diambil dari Kelurahan Parit Culum II Kecamatan Muara Sabak Barat Provinsi Jambi, etanol 70\% (Merck), $\mathrm{AlCl}_{3}$ 5\% (Merck), $\mathrm{H}_{2} \mathrm{SO}_{4} 10 \%$ (Merck), plat kromatografi KLT, silika gel (silika G 60 kode 1.07734), kromatografi kolom (silika G 60 kode 1.07731), dan preparatif (silika GF254 1.07730), media nutrient agar (NA), media nutrient broth (NB), zat kimia lain yang diperlukan untuk skrining.

Alat yang digunakan yaitu maserator, timbangan analitik, seperangkat vacum rotary evaporator, Lampu UV $254 \mathrm{~nm}$ dan $366 \mathrm{~nm}$, botol kaca gelap, vial, seperangkat alat KLT, autoklaf, incubator/oven, plastik wrap, mikropipet, aluminium voil dan alat-alat gelas yang umum dipakai.

\section{Prosedur kerja}

Ekstraksi

Identifikasi tumbuhan Sembung Rambat dilakukan di Laboratorium Identifikasi dan Determinasi Biota, Sekolah Ilmu dan Teknologi Hayati (SITH), Institut Teknologi Bandung. Sebanyak $10 \mathrm{~kg}$ daun Sembung Rambat segar dicuci dengan air dan dikeringanginkan sampai beratnya konstan. Sampel yang sudah kering dihaluskan dengan blender hingga menjadi serbuk daun Sembung Rambat. Serbuk daun sembung rambat ditimbang sebanyak $2 \mathrm{~kg}$, lalu direndam dengan etanol 70\%. Proses maserasi dilakukan selama 3×24 jam hingga diperoleh filtrat bening. Semua filtrat yang dihasilkan dicampurkan, kemudian dipekatkan dengan menggunakan vacum rotary evaporator pada suhu $50^{\circ} \mathrm{C}$ sampai didapat ekstrak kental. (Polakitan et al., 2017) 
DOI: $10.22437 /$ chp.v3i2.5554

Chempublish Journal, Volume 3 No 2 (2018), 40-45

\section{Penapisan Fitokimia Ekstrak}

Penapisan fitokimia ekstrak daun Sembung Rambat meliputi pemeriksaan Alkaloid, Flavonoid, Polifenol, Tanin, Saponin, Steroid, Terpenoid, Monoterpenoid dan Seskuiterpenoid (Harborne, 1987; Dewi et al, 2013; Dapas et al, 2014; Jannah et al, 2017)

\section{Kromatografi Lapis Tipis Ekstrak Daun Sembung Rambat}

Ekstrak etanol daun sembung rambat dilakukan uji KLT untuk memonitor senyawa yang terkandung didalamnya. Dimana dalam proses ini diuji berbagai campuran pengembang untuk mencari campuran pengembang yang baik.

\section{Uji Aktivitas Antibakteri}

Pengujian aktivitas antibakteri menggunakan metode cakram dilakukan terhadap ekstrak etanol. Bakteri Staphylococcus aureus diambil dari biakan di Laboratorium Mikrobiologi STIKES Harapan Ibu Jambi. Adapun langkah-langkah uji aktivitas tersebut adalah (1) Sterilisasi alat menggunakan oven pada suhu $170^{\circ} \mathrm{C}$ selama \pm 2 jam, sedangkan ose dan pinset disterilkan dengan cara pemijaran dan didinginkan sebelum digunakan. Media tumbuh bakteri disterilkan dalam autoklaf pada suhu $121^{\circ} \mathrm{C}$ selama 15 menit. (Aswarita, 2013); (2) Pembuatan Media Nutrient Agar (NA) dan Nutrient Broth (NB) sebanyak $5 \mathrm{~g}$ kedalam $250 \mathrm{ml}$ aquadest dan disterilkan menggunakan autoklaf pada suhu $121^{\circ} \mathrm{C}$ selama 15 menit. Media untuk peremajaan diletakkan miring pada suhu ruang selama 24 jam. Media cair (Nutrient Broth) dibuat sebanyak 0,24 g Nutrient Broth (NB) kedalam $30 \mathrm{~mL}$ aquadest sebagai media tumbuh bakteri dan disterilkan menggunakan autoklaf pada suhu $121^{\circ} \mathrm{C}$ selama 15 menit. (Maharani, Sukandar, \& Hermanto, 2016); (3) Penyiapan Kultur Murni: Biakan murni bakteri diremajakan pada media padat agar miring dengan cara menggoreskan jarum ose yang mengandung bakteri $\mathrm{S}$. aureus secara aseptis dan diinkubasi selama 24 jam pada suhu $37^{\circ} \mathrm{C}$ dalam inkubator. (Maharani et al., 2016); (4) Pembuatan Suspensi Bakteri Uji: Bakteri diambil dengan ose lalu disuspensikan dengan 30 $\mathrm{mL}$ media NB (Nutrient Broth) yang sudah steril, lalu dihomogenkan dengan menggunakan rotary shaker. (Zakiyah et al, 2015). Suspensi bakteri selanjutnya ditentukan konsentrasinya dengan menggunakan spektro dengan panjang gelombang $625 \mathrm{~nm}$, dengan kerapatan bakteri sebesar 1-2 x $10^{8} \mathrm{CFU} / \mathrm{ml}$ dan kekeruhan bakteri absorbansi sebesar 0,08 - 0,1. (Aswarita, 2013;Polakitan et al., 2017); (5) Penyiapan Media Tumbuh Bakteri: Media padat (NA) dicairkan dan didinginkan $\left(\leq 45^{\circ} \mathrm{C}\right)$. Satu $\mathrm{mL}$ larutan biakan aktif dimasukkan kedalam cawan petri steril. Selanjutnya dituangkan media yang masih cair kedalam cawan petri steril dan dihomogenkan dengan memutar cawan petri mengikuti pola angka delapan. Lalu didiamkan hingga memadat. (Mewari \& Kumar, 2008); (6) Uji Daya Hambat Bakteri: Sampel uji yang sudah dipekatkan ditimbang dan dilarutkan dengan menggunakan pelarut organik. Selanjutnya sampel diteteskan kekertas cakram steril sebanyak $10 \mu \mathrm{L}$ dan didiamkan selama \pm 15 menit. Uji daya hambat dilakukan dengan menggunakan metode Kirby-Bauer atau metode difusi cakram. Kertas cakram yang telah 
DOI: $10.22437 /$ chp.v3i2.5554

Chempublish Journal, Volume 3 No 2 (2018), 40-45

ditetesi ekstrak diletakkan diatas pemukaan agar yang berisi bakteri uji. Selanjutnya, diinkubasi pada suhu $37^{\circ} \mathrm{C}$ selama 24 jam. Lalu diukur zona hambatnya dengan menggunakan jangka sorong. (Zakiyah et al., 2015)

\section{PEMBAHASAN}

Identifikasi tumbuhan dilakukan untuk menentukan jenis tumbuhan yang digunakan. Hasil identifikasi menunjukkan bahwa tumbuhan yang diperoleh merupakan Mikania micrantha Kunth yang berasal dari suku Asteraceae. Daun Sembung rambat dicuci bersih dengan air yang mengalir guna menghilangkan kotoran yang melekat pada daun. Daun dikeringanginkan untuk mengurangi kadar air yang ada pada daun. Pengecilan ukuran dengan blender bertujuan untuk memperbesar luas permukaan simplisia, sehingga lebih mudah dalam mengekstrak metabolit sekunder dari dalam daun (Wati et al, 2017).

Pembuatan ekstrak dilakukan dengan metode maserasi atau perendaman dengan menggunakan pelarut organik dengan tujuan agar pelarut yang digunakan dalam proses maserasi akan masuk ke dalam sel tanaman melewati dinding sel karena adanya perbedaan konsentrasi antara larutan di dalam dengan di luar sel melalui proses difusi yang menyebabkan terjadinya pemecahan dinding sel dan membran sel sehingga senyawa metabolit sekunder yang terdapat di dalam sel akan terlarut dalam pelarut organik (Rahmi et al., 2016).

Dari proses maserasi simplisia daun Sembung Rambat didapatkan rendemen sebesar 25,14\%. Serbuk simplisia diekstraksi dengan menggunakan etanol 70\%. Dari penapisan fitokimia, metabolit sekunder yang terkandung dalam ekstrak daun Sembung Rambat dapat dilihat pada Tabel 1.

Tabel 1. Hasil Skrining Fitokimia Ekstrak Daun Sembung Rambat

\begin{tabular}{lc}
\hline Golongan Senyawa & Ekstrak Etanol \\
\hline Alkaloid (Mayer) & + \\
Alkaloid (Dragendorff) & + \\
Flavonoid & + \\
Polifenol & + \\
Tanin & - \\
Saponin & + \\
Steroid & + \\
Terpenoid & - \\
Monoterpen dan sesquiterpen & - \\
\hline Keterangan: $\quad(+):$ Terdeteksi &
\end{tabular}

Ekstrak simplisia daun sembung rambat dilakukan KLT dengan pelarut n-heksan: etil asetat (1:1). Pemantauan pola bercak dilakukan di bawah sinar UV $254 \mathrm{~nm}$ dan 366 nm dengan penampak bercak $\mathrm{H}_{2} \mathrm{SO}_{4} 10 \%$ dan $\mathrm{AlCl}_{3} 5 \%$. Cairan penampak $\mathrm{H}_{2} \mathrm{SO}_{4}$ ini dipilih karena diketahui bahwa larutan ini merupakan penampak bercak yang umum digunakan untuk melihat senyawa metabolit primer ataupun senyawa metabolit sekunder. Sedangkan untuk penampak bercak $\mathrm{AlCl}_{3} 5 \%$ digunakan karena larutan ini merupakan penampak 
bercak untuk melihat senyawa metabolit sekunder golongan flavonoid. Dari hasil KLT dilihat dibawah sinar UV $254 \mathrm{~nm}$ diperoleh 3 bercak dengan nilai Rf sebesar 0.175, 0.4, dan 0.575. Dilihat di bawah sinar UV $366 \mathrm{~nm}$ terlihat 4 bercak dengan nilai Rf sebesar $0.075,0.2,0.35$, dan 0.575. (Gambar 1).
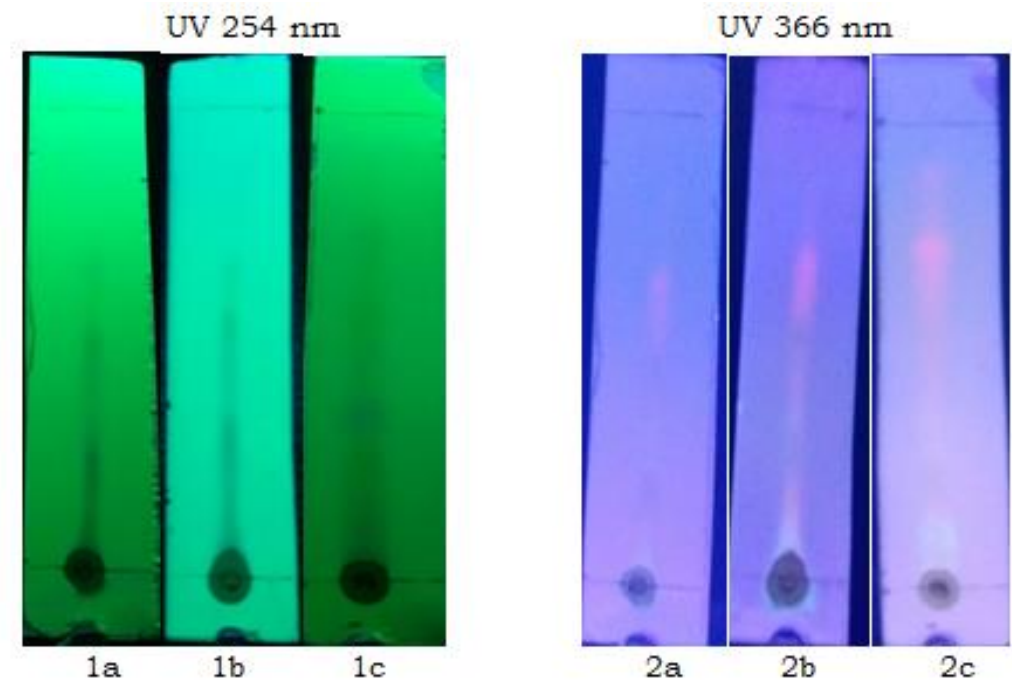

\section{Keterangan \\ Fase Diam \\ Fase Gerak \\ Deteksi}

Gambar 1. Hasil KLT ekstrak daun Sembung Rambat

$$
\begin{aligned}
& \text { : Silika Gel } 60 \mathrm{~F}_{254} \\
& : \text { N-heksan : Etil Asetat (1:1) } \\
& : \text { 1a.Sinar UV } 254 \mathrm{~nm} \text { (Tanpa penampak bercak) } \\
& \text { 1b. Sinar UV } \left.254 \mathrm{~nm} \text { (Penampak } \mathrm{H}_{2} \mathrm{SO}_{4} 10 \%\right) \\
& \text { 1c. Sinar UV } \left.254 \mathrm{~nm} \text { (Penampak } \mathrm{AlCl}_{3} 5 \%\right) \text { ) } \\
& \text { 2a. Sinar UV } 366 \mathrm{~nm} \text { (Tanpa penampak bercak) } \\
& \text { 2b. Sinar UV } \left.366 \mathrm{~nm} \text { (Penampak } \mathrm{H}_{2} \mathrm{SO}_{4} 10 \%\right) \\
& \text { 2c. Sinar UV } \left.366 \mathrm{~nm} \text { (Penampak } \mathrm{AlCl}_{3} 5 \%\right)
\end{aligned}
$$

Pengujian aktivitas antibakteri dilakukan dengan menggunakan metode Kirbybauer atau metode difusi cakram. Berdasarkan hasil pengukuran zona bening yang terbentuk pada uji daya hambat, diketahui bahwa ekstrak daun sembung rambat memberikan daya hambat terhadap bakteri Staphylococcus aureus.

Tabel 2. Kategori kekuatan zat antibakteri berdasarkan diameter zona hambat (Saridewi et al, 2018)

\begin{tabular}{ll}
\hline Diameter Daya Hambat & \multicolumn{1}{c}{ Daya Hambat } \\
\hline$>20 \mathrm{~mm}$ & Sangat kuat \\
$11-20 \mathrm{~mm}$ & Kuat \\
$6-10 \mathrm{~mm}$ & Sedang \\
$<5 \mathrm{~mm}$ & Lemah \\
\hline
\end{tabular}

Bakteri Staphylococcus aureus pada ekstrak dengan konsentrasi 5\% telah memberikan daya hambat yang kuat dimana zona hambat yang terbentuk dari ekstrak $5 \%, 10 \%$, dan $15 \%$ secara berurutan memberikan daya hambat sebesar $16.03 \mathrm{~mm}, 12.082$ $\mathrm{mm}$, dan $16.32 \mathrm{~mm}$ (Tabel 2).

\section{KESIMPULAN}

Ekstrak daun Sembung Rambat memiliki daya hambat antibakteri yang kuat terhadap bakteri Staphylococcus aureus. 


\section{UCAPAN TERIMA KASIH}

Terima kasih diucapkan kepada Kementrian Riset, Teknologi dan Perguruan Tinggi atas dana hibah PDP No. kontrak 042/KONTRAK-PENELITIAN/K10/KM/2017.

\section{DAFTAR PUSTAKA}

Aswarita, R. 2013. Interaksi Ekstrak Daun Lidah buaya (Aloe vera L.) dan Daun Jambu Biji (Psidium guajava L.) Terhadap Daya Hambat Escherichia coli Secara In Vitro. EduBio Tropika, 1(2), 115-120.

Chetia, J., Upadhyaya, S., \& Bora, D. K. 2014. Research Article Screening of Phytochemicals, Antioxidant and Antimicrobial Activity of Some Tea Garden Weeds of Tinsukia, Assam., 26(33), 193-196.

Dapas, C. C., Koleangan, H. S. J., \& Sangi, M. 2014. Analisis Senyawa Metabolit Sekunder dan Uji Toksisitas Ekstrak Batang Bawang Laut ( Proiphys amboinensis ( L .), 3(2), 144-148.

Dewi, Astuti, \& Warditiani. 2013. Skrining Fitokimia Ekstrak Etanol 95 \% Kulit Buah Manggis (Garcinia mangostana L .).

Haisya, N. B. S., Latifah, A. R., Suratno, R. P., Sa'diah, S., \& Afiff, U. 2013. Sembung Rambat (Mikania micrantha H . B . K .) as Natural Alternative Antibacterial and Its Study in Cattle Mastitis in Indonesia, 3-5.

Harborne J.B. 1987. Metode Fitokimia: Penuntun Cara Modern Menganalisis Tumbuhan, Penerjemah:Kosasih, P. dan Iwang Soediro. bandung.

Jannah, R., Husni, M. A., \& Nursanty, R. 2017. Inhibition Test of Methanol Extract From Soursop Leaf (Annona muricata Linn.) Against Streptococcus mutans BACTERIA, 17(1), $11-12$.

Lallianchhunga, M. ., Ali, M. A., Lalchhandama, C., Lalmuanthanga, C., \& Devi, L. I. 2016. Antioxidant Activity of Methanolic Extract of Mikania Micrantha Leaves. World Journal of Pharmaceutical Research, 5(4), 879-886.

Li, Y., Li, J., Li, Y., Wang, X., \& Cao, A. 2013. Antimicrobial Constituents of the Leaves of Mikania, 8(10).

Maharani, T., Sukandar, D., \& Hermanto, S. 2016. Karakterisasi Senyawa Hasil Isolasi dari Ekstrak Etil Asetat Daun Namnam (Cynometra Cauliflora L.) yang Memiliki Aktivitas Antibakteri, 2(1), 55-62.

Matawali, A., Chin, L. P., \& Gansau, J. A. 2016. Antibacterial and Phytochemical Investigations of Mikania micrantha H.B.K. (Asteraceae) From Sabah, Malaysia, Transactions on Science and Technology. 3(1-2), 244 - 250.

Mewari, N., \& Kumar, P. 2008. Antimicrobial activity of extracts of Marchantia polymorpha. Pharmaceutical Biology, 46(10-11), 819-822.

Perez-amador, Ocotero, V. M., Balcazar, R. I., \& Jimenez, F. G. 2010. Phytochemical and pharmacological studies on Mikania micrantha H . B . K . (Asteraceae ), 77-80.

Polakitan, I. R., Leman, M. A., \& Fatimawali. 2017. Uji Daya Hambat Ekstrak Daun Sembung Rambat ( Mikania micrantha) Terhadap Pertumbuhan Streptococcus mutans. PHARMACON Jurnal Ilmiah Farmasi - UNSRAT Vol. 6 No. 1, 6(1), 1-8.

Rahmi, Herawati, N., \& Dini, I. 2016. Isolasi dan Identifikasi Senyawa Metabolit Sekunder Ekstrak Etil Asetat Kulit Batang Belimbing Wuluh ( Averrhoa bilimbi Linn ). Jurnal Chemica, 17(1), 98-107.

Saridewi, M. N., Bahar, M., \& Anisah. 2018. Uji Efektivitas Antibakteri Perasan Jus Buah Nanas ( Ananas comosus ) Terhadap Pertumbuhan Isolat Bakteri Plak Gigi di Puskesmas Kecamatan Tanah Abang Periode April 2017, 5(2), 104-110.

Wati, M., Erwin, \& Tarigan, D. 2017. Isolasi dan Identifikasi Senyawa Metabolit Sekunder dari Fraksi Etil Asetat Pada Daun Berwarna Merah Pucuk Merah ( Syzygium MyrtifiliumWalp. ). Kimia FMIPA Unmul Isolasi, 14(2), 100-107.

Zakiyah, A., Radiastuti, N., \& Sumarlin, L. O. 2015. Aktivitas Antibakteri Kapang Endofit Dari Tanaman Kina ( Cinchona calisaya Wedd .). Jurnal Biologi, 8, 51-58. 